\title{
The role of statins in lung cancer
}

\author{
Fatemeh Amin ${ }^{1,2}$, Farzaneh Fathi' ${ }^{3}$ Željko Reiner ${ }^{4}$, Maciej Banach ${ }^{5,6}$, Amirhossein Sahebkar ${ }^{7,8,9}$
}

\author{
${ }^{1}$ Physiology-Pharmacology Research Center, Research Institute of Basic Medical \\ Sciences, Rafsanjan University of Medical Sciences, Rafsanjan, Iran \\ 2Department of Physiology and Pharmacology, School of Medicine, Rafsanjan \\ University of Medical Sciences, Rafsanjan, Iran \\ ${ }^{3}$ Pharmaceutical Sciences Research Center, Biosensor and Bioelectronic Department, \\ Ardabil University of Medical Sciences, Ardabil, Iran \\ ${ }^{4}$ Department of Internal Medicine, University Hospital Centre Zagreb, \\ School of Medicine, University of Zagreb, Zagreb, Croatia \\ ${ }^{5}$ Department of Preventive Cardiology and Lipidology, Medical University of Lodz, \\ Lodz, Poland \\ ${ }^{6}$ Polish Mother's Memorial Hospital Research Institute (PMMHRI), Lodz, Poland \\ ${ }^{7}$ Applied Biomedical Research Center, Mashhad University of Medical Sciences, \\ Mashhad, Iran \\ ${ }^{8}$ Biotechnology Research Center, Pharmaceutical Technology Institute, \\ Mashhad University of Medical Sciences, Mashhad, Iran \\ ${ }^{9}$ School of Pharmacy, Mashhad University of Medical Sciences, Mashhad, Iran
}

Submitted: 2 March 2020; Accepted: 1 June 2020

Online publication: 18 March 2021

Arch Med Sci 2022; 18 (1): 141-152

DOI: https://doi.org/10.5114/aoms/123225

Copyright @ 2021 Termedia \& Banach

\begin{abstract}
Lung cancer is one of the most common causes of cancer-related mortality in the $21^{\text {st }}$ century. Statins as inhibitors of 3-hydroxy-3-methylglutaryl coenzyme A reductase not only reduce the cholesterol levels in the blood and decrease the risk of cardiovascular disease but may also play an important role in the prevention and treatment of lung cancer. Statins have several antitumor properties including the ability to reduce cell proliferation and angiogenesis, decrease invasion and synergistic suppression of lung cancer progression. Statins induce tumor cell apoptosis by inhibition of downstream products such as small GTP-binding proteins, Rho, Ras and Rac, which are dependent on isoprenylation. Statins reduce angiogenesis in tumors by down-regulation of pro-angiogenic factors, such as vascular endothelial growth factor. In this review, the feasibility and efficacy of statins in the prevention and treatment of lung cancer are discussed.
\end{abstract}

Key words: statins, lung cancer, apoptosis, non-small cell lung cancer.

\section{Introduction}

Lung cancer (LC) is one of the most common cancers worldwide, and high mortality rates are reported in both males and females for this cancer. It is commonly divided into small cell lung cancer (SCC) and nonsmall cell lung cancer (NSCLC). Non-small cell lung cancer accounts for the majority of all LCs - more than $80 \%$ (it includes adenocarcinomas, large cell carcinomas and squamous cell carcinomas) [1, 2]. Smoking and occupational pollution with substances such as asbestos, lead, copper, arsenic, and polycyclic aromatic hydrocarbons are the most important risk factors for LC. Therefore, early preventive measures and research on the environmental causes of LC are of crucial importance today. Other

\author{
Corresponding author: \\ Amirhossein Sahebkar \\ PharmD, PhD \\ Department of Medical \\ Biotechnology \\ School of Medicine \\ Mashhad University \\ of Medical Sciences \\ Mashhad, Iran \\ P.O. Box: 91779-48564, Iran \\ Phone: 985138002288 \\ Fax: 985138002287 \\ E-mails: \\ sahebkara@mums.ac.ir; \\ amir_saheb2000@yahoo.com
}


risk factors for LC include genetic factors, dietary factors, and lung diseases such as pulmonary fibrosis and chronic obstructive lung disease [1]. Moreover, genetic factors are another predisposing factors for NSCLC $[3,4]$. About $95 \%$ of patients with LC are current or former smokers. Lung cancer is an invasive and heterogeneous disease. This cancer is one of the fastest growing cancers; the average time for its development is three to five months [5]. As reported in 2014, $23 \%$ of all cancers are LC [6]. Two essential characteristics of highly malignant $\mathrm{LC}$ are:

1. The tendency of cells to metastasize. In the process of metastasis, a number of signals are activated that produce continuously free radicals, including superoxide $\left(\mathrm{O}_{2}^{--}\right)$, radical hydroxyl $(\mathrm{OH})$, and hydrogen peroxide $\left(\mathrm{H}_{2} \mathrm{O}_{2}\right)$, having several stages: epithelial-mesenchymal transition (EMT), migration to the tissue and angiogenesis [7]. The growth and survival of a cell depend on reactive oxygen species (ROS) homoeostasis. Reactive oxygen species homoeostasis is vital for healthy cells. A moderate increase in ROS can enhance the proliferation and differentiation of cells, while overproduction of ROS damages the cells. Therefore, the production of oxidants or the reduction of superoxide dismutase (SOD) and glutathione peroxidase (GPX) may cause the activation of oncogenes, abnormal metabolism, mitochondrial dysfunction, or the production of cytokines and inflammatory factors. Stimulatory signals causing chronic irritation, infections or inflammation are some of the most important causes of tumor progression $[7,8]$.

2. Resistance to treatment. In spite of huge advances in LC treatment over the past three decades, the current 5-year survival for LC is only $18 \%$ [9]. Even though multiple approaches are recommended for LC treatment such as surgery, chemotherapy, targeted therapy, immunotherapy, and radiotherapy, the mechanisms involved in the resistance of some types of LC cells to treatment are still not fully understood [10, 11].

Some lipid lowering agents such as statins and PCSK9 inhibitors are shown to have preventive effects on cancer development and incidence [12-16]. Statins are still the first-line medications for cholesterol lowering [17] because they are inhibitors 3-hydroxy-3-methyl-glutaryl coenzyme A reductase (HMG-CoA), which is a key enzyme in rate limiting synthesis of cholesterol, particularly in the liver cells [18]. However, these drugs have several pleiotropic and lipid-independent actions [19-24]. Statins used as lipid lowering agents include lovastatin, simvastatin (inactive forms), pravastatin, atorvastatin, fluvastatin (active forms) rosuvastatin and pitavastatin [17].
Recent studies have demonstrated that statins can be useful in preventing or treating cancers, due to interference with vital cell functions such as proliferation and differentiation. They can induce cell death via two mechanisms: apoptosis and necrosis in different cell lines [25]. The induction of apoptosis in cancer cells is one of the functional mechanisms by which chemotherapy drugs work and is essential for treating cancer [26]. The growth inhibitory effects and the pro-apoptotic properties of statins have attracted special attention for their treatment of various cancers, especially LC. This was the reason to review the effects of different statins in LC treatment.

\section{Statins}

Statins are the most effective low-density lipoprotein (LDL) cholesterol-lowering drugs. They are structural analogs of HMG-CoA, which competitively inhibit the enzyme HMG-CoA reductase [27]. $\mathrm{HMG}-\mathrm{Co} A$ reductase is a key enzyme and regulator of the cholesterol synthesis pathway that catalyzes the conversion of HMG-CoA to mevalonate and ultimately to cholesterol. The result of inhibiting this enzyme is the inhibition of liver cholesterol production. The compensatory response to decreased hepatic cholesterol is an increase in the expression of $L D L$ receptors on the surface of hepatocytes, resulting in increased clearance of cholesterol rich LDL particles from the blood and a decrease in their plasma levels. The major application of statins is to prevent the atherosclerotic disease [28].

Statins have lipid-lowering properties but also different side effects. Hydrophilic statins, such as pravastatin and fluvastatin, have less influence on cell membrane permeability, resulting in less pleiotropic properties and fewer adverse effects on the muscular system and central nervous system. Lipophilic statins, such as simvastatin, lovastatin, and atorvastatin, have more pleiotropic properties and side effects [29].

Lovastatin is an inactive lactone prodrug causing proteasome inhibition. It is a fungal metabolite isolated from cultures of Aspergillus terreus. Simvastatin is the chemically modified form of lovastatin [30]. Fluvastatin is the first fully synthetic HMG-COA reductase inhibitor. The characteristics of fluvastatin include minimal systemic exposure, short half-life, and high affinity to protein binding [31]. There were some reports that fluvastatin causes less rhabdomyolyses when compared with other statins [32]. It is absorbed from the gastrointestinal tract and metabolized into the 6-hydroxy and $\mathrm{N}$-desisopropyl fluvastatin by cytochrome P450 (CYP) 2C9 in the liver [33]. In some countries fluvastatin was prescribed more frequently than other statins as a first choice for treatment of hypercholesterolemia [34]. Rosuvastatin is one 
of the new generation of fully synthetic HMG-CoA reductase inhibitors with some unique properties. It has low lipophilicity and high protein binding affinity [35]. Rosuvastatin has a relatively long elimination half-time and has low systemic bioavailability [36]. Since it contains a polar methyl sulfonamide group, rosuvastatin interacts with HMG-CoA reductase in hepatocytes. Similarly to other statins, rosuvastatin is extensively prescribed for reduction of atherogenic plasma lipoproteins, primarily LDL and LDL cholesterol [37]. Pravastatin - the most hydrophilic drug - is relatively soluble in water and methanol [38]. Although it is quickly absorbed following oral administration, it has low bioavailability due to its ineffective $a b-$ sorption [39]. Pravastatin clearance is performed by the liver and kidneys and it has low affinity to protein binding [40]. Pravastatin is selectively taken up by the sodium-independent organic anion transporter protein-1B1 (OATP1B1), which is expressed in hepatocytes [41]. Pitavastatin is another member of the statin family with the following structure: heptanoate as the basic structure; a core quinoline ring, and side chains that include fluorophenyl and cyclopropyl moieties [42].

\section{Mechanism of antitumor action of statins}

Several studies have indicated that statins can cause induction of apoptosis in different tumor cells. Possible mechanisms of induction of apop- tosis by statins are due to their role in inhibiting HMG-COA reductase and mevalonate synthesis. Mevalonate, in addition to cholesterol, is a precursor of isoprenoid molecules such as farnesyl pyrophosphate (FPP) and geranylgeranyl pyrophosphate (GGPP). Binding of these molecules to some cellular proteins including $G$ membrane proteins and isoprenylation of these proteins are essential for their function $[43,44]$. Ras and Rho are among the most well-known isoprenylation proteins involved in the transfer of important cellular signals for transcription of genes associated with cell survival activities, including proliferation, differentiation and apoptosis. Statins have important effects on the cell because of changing the function of these proteins (Figure 1).

In various studies, increased expression of the pro-apoptotic molecules Bak, Bim, and Bax, decreased expression of apoptosis inhibitor molecules such as Bcl-2 and activation of caspases have been observed after statin therapy. In mammalian cells at least one of the main proteins - BH123, BAX and BAK - is needed in apoptosis using the intrinsic pathway. Activation of BAX and BAK proteins is dependent on the activation of $\mathrm{BH} 3$ pro-apoptotic proteins [45]. BAK and Bax activated by cytosol enter the mitochondrial outer membrane and disrupt the membrane permeability.

$\mathrm{Bcl}-2$ family apoptosis inhibitor molecules prevent their oligomerization and activation by binding to the $\mathrm{BH} 3$ region in pro-apoptotic mole-

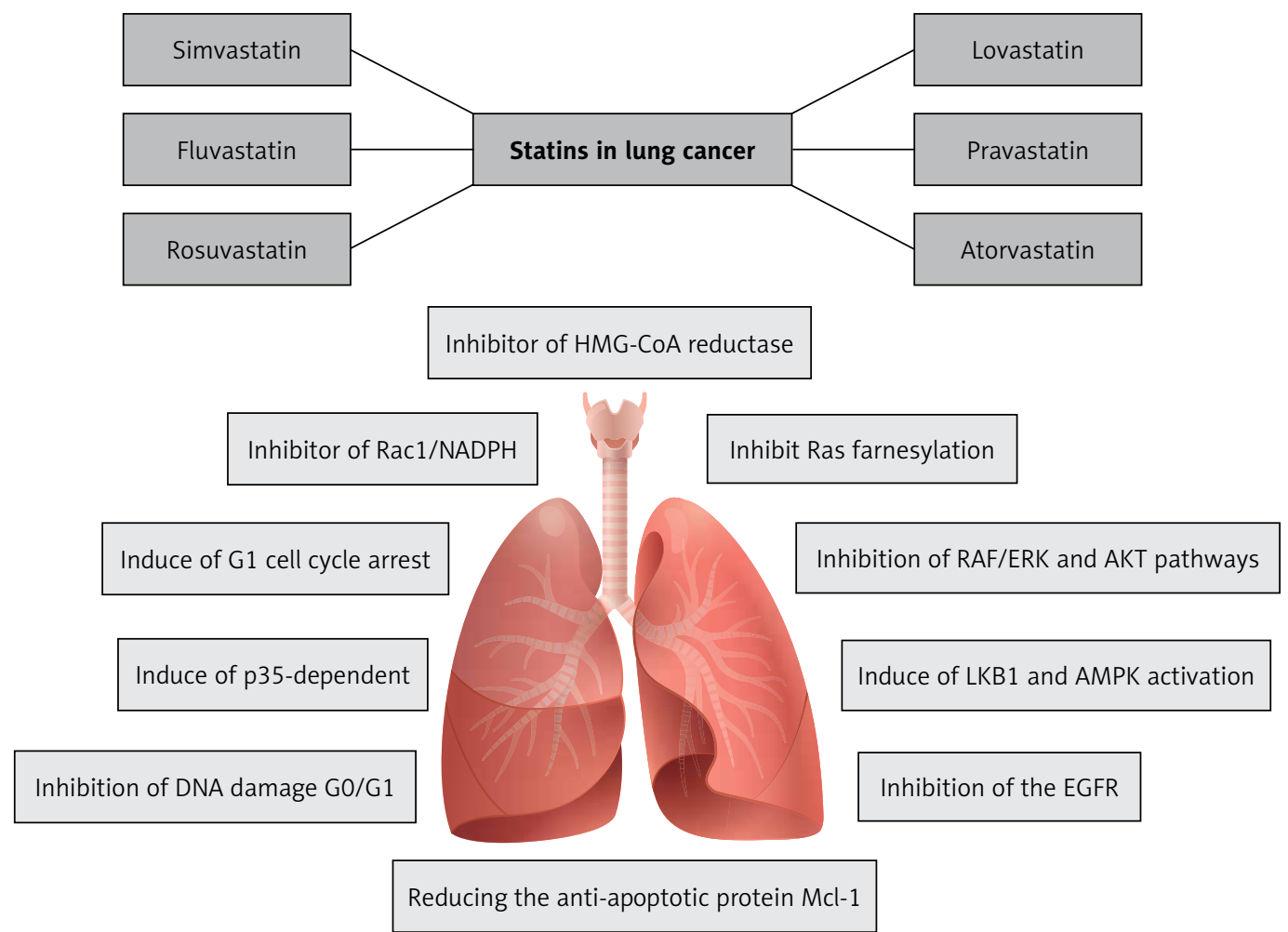

Figure 1. Functional pathway and effect of HMG-CoA reductase enzyme on the activity of Rho/Ras 
cules [46]. Increasing $\mathrm{BCl}-\mathrm{XL}$ or $\mathrm{Bcl}-2$ expression effectively inhibits apoptotic responses to cytotoxic stimuli by inhibiting ROS production, by blocking mitochondrial permeability pores, and by preventing cytochrome $C$ release. In addition to its anti-apoptotic effect on mitochondria, $\mathrm{Bcl}-2$ can inhibit pathways independent of Apaf-1 and caspase 9 and caspase-7-dependent pathways by indirect control of apoptosome activation.

By reducing the expression of pro-angiogenic factors such as vascular endothelial growth factor, statins inhibit angiogenesis in tumor tissues [47]. Vascular endothelial growth factor, an endothelial cell-specific factor, is strongly related to tumor angiogenesis and the metastatic potential of NSCLCs. Moreover, statins inhibit angiogenesis by reducing the proliferation of endothelial cells and preventing their binding to the extracellular matrix [48].

Moreover, one of the alternative effects of statins in preventing cancer is believed to be due to a mild increase in high-density lipoprotein cholesterol (HDL-C) levels, which has not been confirmed in mechanistic studies [49]. The role of serum HDL-C in the incidence of cancer or mortality remains controversial due to its various impacts on tumorigenesis [50-52].

\section{Antitumor effects of statins in preclinical and clinical studies}

Preclinical and clinical evidence has indicated that statins have anti-proliferative, pro-apoptotic and anti-invasive properties. In 2016 it was shown that lovastatin caused a decrease in viability and induction of DNA fragmentation in lung carcinoma [53]. The authors reported that high intracellular levels of the lactone caused apoptotic cell death by upregulation of COX-2 mRNA and protein, as well as increased formation of peroxisome proliferator activated receptor $\gamma$ (PPAR $\gamma$ )-activating PGD2. Lovastatin can also stimulate tumor apoptosis in squamous cell carcinomas (SCC) by two pathways: 1) stimulation of the integrated stress response (ISR) and 2) by inhibition of ligand induced activation of the epidermal growth factor receptor (EGFR) [54], which resulted in stabilized end-stage disease in $23 \%$ of SCC patients treated with lovastatin [55].

The effect of combining lovastatin with gefitinib, a tyrosine kinase inhibitor (TKI), on gefitinib-resistant LC cell lines was also studied. The results showed that gefitinib plus lovastatin considerably improved cell growth inhibition and cytotoxicity in gefitinib-resistant NSCLC cells when compared with gefitinib alone. This could suggest that the antitumor effect is related to the up-regulation of cleaved caspase-3, poly (ADP-ribose) polymerase (PARP) and Bax, and down regulation of Bcl-2 [56]. The potential of lovastatin to induce liver kinase B1(LKB1) and AMPK as a highly conserved heterotrimeric kinase complex activity was investigated as well [57]. The effects on various metabolic stress pathways including the LKB1/ AMPK pathway improve the capacity of lovastatin to act synergically with gefitinib in SCC cells.

The inhibitory effect of lovastatin on Ras farnesylation was investigated as well [58]. In human lung adenocarcinomas Kras alleles are activated by mutations and the inhibition of this has an important role in LC prevention. Some enzymes such as farnesyltransferase and inhibitors of HMG-CoA reductase inhibit Ras farnesylation [59]. It has been shown that lovastatin can destroy the formation of the tobacco-specific nitrosamine-induced lung tumors in a dose-related way without the presence of mutated ras or changes in Kras expression. The protective effect of lovastatin on normal cells against cisplatin (CDDP) cytotoxicity was assessed too [60]. CDDP is a usual chemotherapeutic drug used for the treatment of numerous solid tumors. The authors reported that lovastatin at the pharmacologically relevant concentration per se induced DNA damage, autophagy and oxidative stress in a human lung adenocarcinoma cell line but not in normal human mesothelial primary cells. Therefore, in cancer patients, lovastatin might improve the therapeutic index of cisplatin-based chemotherapy. Zhang et al. investigated whether lovastatin inhibits proliferation due to minichromosome maintenance (MCM) 2 in human NSCLC [61]. They measured the effects of lovastatin on cell anti-proliferation, cell cycle progression and apoptosis in NSCLC cells. Recent studies have also shown that a novel anti-proliferation mechanism of MCM2 could be used for potential therapeutic effects in NSCLCS by knockdown of MCM2 inhibiting not only the G1/S cell cycle but also by activation of apoptosis. Lovastatin has been used in vivo as an inhibitor of tumor progression in various tumor models such as colon, pancreas, and melanoma [62-64]. It has been shown that high doses of lovastatin (0, 25 and $50 \mathrm{mg} / \mathrm{kg} 3$ times a week) were able to inhibit lung metastases in vitro in syngeneic BALB/C mice [65]. In this study, the effects of lovastatin in mammary cancer cells stopped the G1 phase and decreased $\mathrm{S}$ and $\mathrm{G} 2 / \mathrm{M}$ phases of the cell cycle.

Several investigations in vitro and epidemiologic studies have indicated antitumor effects and protective effects of atorvastatin decreasing the risk of LC $[66,67]$. Platinum-based chemotherapy is often used for treatment of progressive NSCLCS. Previous studies have shown that atorvastatin when combined with carboplatin had better effects on the apoptosis of NSCLC when compared with either drug applied as monotherapy [56]. 
It has been shown that treatment of LC using atorvastatin in combination with carboplatin decreased the progression of xenograft A549 tumors in mice by suppressing AKT activity and improved the survival when compared with carboplatin treatment as monotherapy [68, 69].

Lu et al. investigated the synergistic action of Polyphenon E (PPE, green tea polyphenol) and atorvastatin on the inhibitory effect in a mouse model and in vitro [70]. Their results indicated that PPE or atorvastatin alone was not effective in suppressing lung carcinogenesis. The combination of PPE and atorvastatin in low amounts reduced both the tumor growth and tumor expansion.

This synergistic effect of PPE plus atorvastatin was associated with improved apoptosis as determined by the terminal deoxyribonucleotide transferase based nick-end labeling assay. The combination of PPE plus atorvastatin had an additional effect in decreasing the antiapoptotic protein $\mathrm{Mcl}-1$ level and the effect on caspase- 3 and cleaved poly (ADP)-ribose polymerase level, which was different from monotherapy with each of these substances. This study showed that PPE plus atorvastatin synergistically inhibited 4-(methylnitrosamino)-1(3-pyridyl)-1-butanone induced lung tumorigenesis in mice and the growth of LC H1299 and H460 cells, probably by increased apoptosis [70].

Recent studies have shown that cancer cells include poor antioxidant defense. Simvastatin, due to oxidative stress metabolites and SOD2 expression, causes an increase in the regulation of A549 protein and inhibition of cancer cell development [71]. The beneficial effects of treatment with a combination of cisplatin and simvastatin on patients with SCC have also been demonstrated. Such treatment reduced renal toxicity in these patients, and even increased their life span [72]. It is well known that smoking causes DNA damage and LC. The level of metalloproteins in the plas$\mathrm{ma}$ is increased, and the level of RAS proteins is decreased, which results in the activator protein-1 (AP-1), by PI3K/Akt, JNK, p38 MAPK, and ERK signaling pathways [73]. SIM-induced G1 cell cycle stopping in $\mathrm{NCl}-\mathrm{H} 460$ cells is mediated by the upregulation of $\mathrm{p} 16$ and $\mathrm{p} 27$ proteins, and induces blockade of cyclin D-Cdk4 expression. All these phenomena result in the inhibition of proliferation of NSCLC and reduction of the number of cells in $S$ phase and $\mathrm{G} 1$ of the cell cycle. This suggests that the cell cycle-suppressing activity of simvastatin is associated with its anti-cancer properties [74]. BIM is an active agent of apoptotic protein, and it has been reported that simvastatin causes expression of BIM, inhibition of ERK protein signals, and the death of apoptotic cells in H1975 cell culture. These effects were mediated by expression of the BIM protein. Epithelial to mesenchy- mal transition is pivotal for driving metastasis and recurrence in LC. Since some in vitro studies have shown that statins suppress this transition by inactivating mutant $\mathrm{p} 53$ functions, it has been suggested that simvastatin suppresses it and changes the prognosis of patients with lung adenocarcinoma in a p53 mutation-dependent manner [75]. Finally, it seems that simvastatin might even cause cancer cells to disappear [76].

Preclinical data have demonstrated the antitumor effects of fluvastatin in various cancers. It has been shown that fluvastatin synergistically enhances the anti-proliferative effect of gemcitabine in human pancreatic cancer cells [77]. Furthermore, fluvastatin in combination with cisplatin showed synergistic anti-tumor activity in epithelial ovarian cancer cells by inhibiting the Ras pathway [78]. Previous studies have already indicated that fluvastatin can have prophylactic effects in cancer. In a study on renal cancer, fluvastatin inhibited renal cancer cells time- and dose-dependently by induction of cell cycle arrest and apoptosis in the cells. It was shown that fluvastatin influences this process by up-regulation of p21 and p53 in this type of cancer. Moreover, it can prevent angiogenesis, invasion, and metastasis by decreasing phosphorylation of rac1 in renal cancer cells [31]. Recently, a significant body of evidence has demonstrated the anti-proliferative and chemotherapeutic effects of fluvastatin in LC. After it had been shown that HMG-CoA reductase is overexpressed in human lung adenocarcinoma when compared with normal tissues, fluvastatin, an inhibitor of HMGCoA reductase, suppressed NSCLC cell growth and induced apoptosis by inhibiting the HMG-CoA reductase-driven Braf/MEK/ERK1/2 and Akt signaling pathways. It also attenuated tumor growth in 4-(methylnitrosamino)-1-(3-pyridyl)-1-butanone (NNK)-induced lung tumorigenesis [79].

$\mathrm{Xu}$ et al. reported that fluvastatin significantly reduced in vitro cell proliferation and metastasis of aggressive human NSCLC cells and this effect was time- and dose-dependent. Furthermore, they found that fluvastatin significantly suppressed the in vitro tumor progression probably by down-regulation of SATB1 (Special AT-rich sequence binding protein 1) expression in the human NSCLC cell line H292 [80]. Yang et al. observed that fluvastatin significantly reduced bone metastasis of lung adenocarcinoma in a nude mouse model. They suggested that fluvastatin mainly inhibited bone metastasis by induction of a p53-dependent autophagy process in lung adenocarcinoma cells [81].

Levine and Cagan observed in a Drosophila LC model that oral administration of MEK inhibitor (trametinib) and fluvastatin blocked Ras and PI3K signaling pathways, which decreased survival 
in the models. The combination of these drugs showed synergistic suppression of tumor progression and viability in the models. This combination also exhibited a cytotoxic effect on human lung adenocarcinoma cells [82]. All these data suggest that fluvastatin could be considered as a novel chemotherapeutic agent in cancer, particularly in LC.

Previous studies suggested that rosuvastatin might have an important role in therapy of various cancers. In a randomized clinical trial in women with breast cancer, it was found that rosuvastatin prevented the development of chemotherapy-induced cardiotoxicity [83]. In addition, rosuvastatin enhanced the anti-cancer effect of dasatinib in hepatocellular carcinoma via inhibiting the FAK/SrC signaling pathway [84]. Yokohama et al. found that rosuvastatin prevented hepatocellular carcinogenesis and improved the hepatic background by down-regulation of the mRNA level of pro-inflammatory cytokines including tumor necrosis factor $\alpha$ (TNF- $\alpha$ ), interleukin 6 (IL-6) and transforming growth factor $\beta 1$ (TGF- $\beta 1$ ) in mice [85]. In melanoma cells, rosuvastatin dose-dependently reduced cell proliferation. Rosuvastatin also down-regulated ki67 expression in melanoma cells in prolonged incubation [86]. Some studies demonstrated that rosuvastatin can reduce the effects of oxidative stress and DNA damage by induction of antioxidant defense enzymes such as $\gamma$-glutamylcysteine synthetase in the cells [87].

Janakiram et al. reported that rosuvastatin alone or in combination with difluoromethylornithine significantly decreased polyamine content in the cells and increased intra-tumoral NK cells expressing perforin and IFN- $\gamma$ when compared to untreated colon tumors [88]. Recently, a large body of evidence has suggested the anti-tumor effect of rosuvastatin in LC. Liu et al. found that statin treatment significantly decreased LC risk in chronic obstructive pulmonary disease (COPD) patients and the effect was dose-dependent. Nevertheless, lovastatin and fluvastatin did not show any significant reduction in LC risk while not only rosuvastatin, but also simvastatin, atorvastatin, and pravastatin significantly decreased LC risk [89]. Simvastatin and rosuvastatin significantly inhibited cell proliferation by suppression of RAS protein, matrix metalloproteinases (MMP-2/9) and NF-кB-p65 expression in LC tissues, and this effect was dose-dependent [90]. However, there are some conflicting data as well. Lai et al. found that rosuvastatin with cumulative use duration $>12$ months was associated with 2.8-fold increased risk of LC in Taiwan women when compared with those who were not treated with statins [91]. Some studies indicated that liposomal pravastatin treatment effectively inhibited the production of several proinflammatory/pro-angiogenic mediators involved in inflammation and angiogenesis in cancer [92]. Inconsistently with previous results, a small randomized phase II clinical trial on thirty patients concluded that addition of pravastatin to epirubicin, cisplatin, and capecitabine did not improve the clinical outcome of the enrolled patients with advanced gastric cancer [93]. A more recent study also showed that pravastatin did not significantly improve clinical outcome in patients with advanced gastric cancer (stage III or IV) [94].

A meta-analysis including 13724 patients demonstrated that pravastatin treatment was not associated with cancer risk. Pravastatin did not influence overall survival of the patients either [95]. Asakage et al. found that pravastatin decreased cell proliferation and growth by cell cycle arrest in $\mathrm{G} 1$ phase due to depleting cyclin D, cyclin E and cyclin-dependent kinase 2 expression levels in endothelial cells [96]. With regards to LC, a multicenter phase III randomized double-blind placebo controlled clinical trial, which investigated the effects of pravastatin added to standard chemotherapy in SCC, showed that pravastatin did not bring any benefit in the patients. The 2-year overall survival (OS) and progression-free survival (PFS) rates of pravastatin and placebo did not show any significant difference [97]. In a recent review on pravastatin in LC, it was concluded that pravastatin did not have any beneficial effects in SCC [98]. Taras et al. demonstrated that pravastatin significantly reduced tumor progression and lung invasion in rat hepatocellular carcinoma. They showed that pravastatin inhibited tumor metastasis to the lung by reducing liver matrix metalloproteinase-9 (MMP-9) activity and suppression of MMP2, which was mainly attributed to down-regulation of MMP14 in hepatocellular carcinoma [99]. In the animal study of Ferreira et al., atorvastatin and pravastatin slightly reduced inflammation and oxidative stress in mice exposed to cigarette smoke in comparison to controls. Rosuvastatin showed the highest antiinflammatory effect and simvastatin achieved the best anti-oxidative response [100]. As mentioned above in the section on rosuvastatin, Liu et al. found that statin significantly reduced LC risk in chronic obstructive pulmonary disease patients and this effect was dose-dependent. They reported that pravastatin was significantly associated with a decreased LC risk [89]. Pravastatin showed a marginal benefit in cancer therapy and further investigation will be needed to explain the exact role and possible effect of pravastatin in cancer.

Otahal et al. found that pitavastatin and fluvastatin induced cell death in EGFR TKI resistant NSCLC cells lines A549, Calu6 and H1993 in vitro. Co-treatment of cells with pitavastatin and the EGFR TKI erlotinib resulted in synergistically enhanced cytotoxicity when compared to pitavas- 


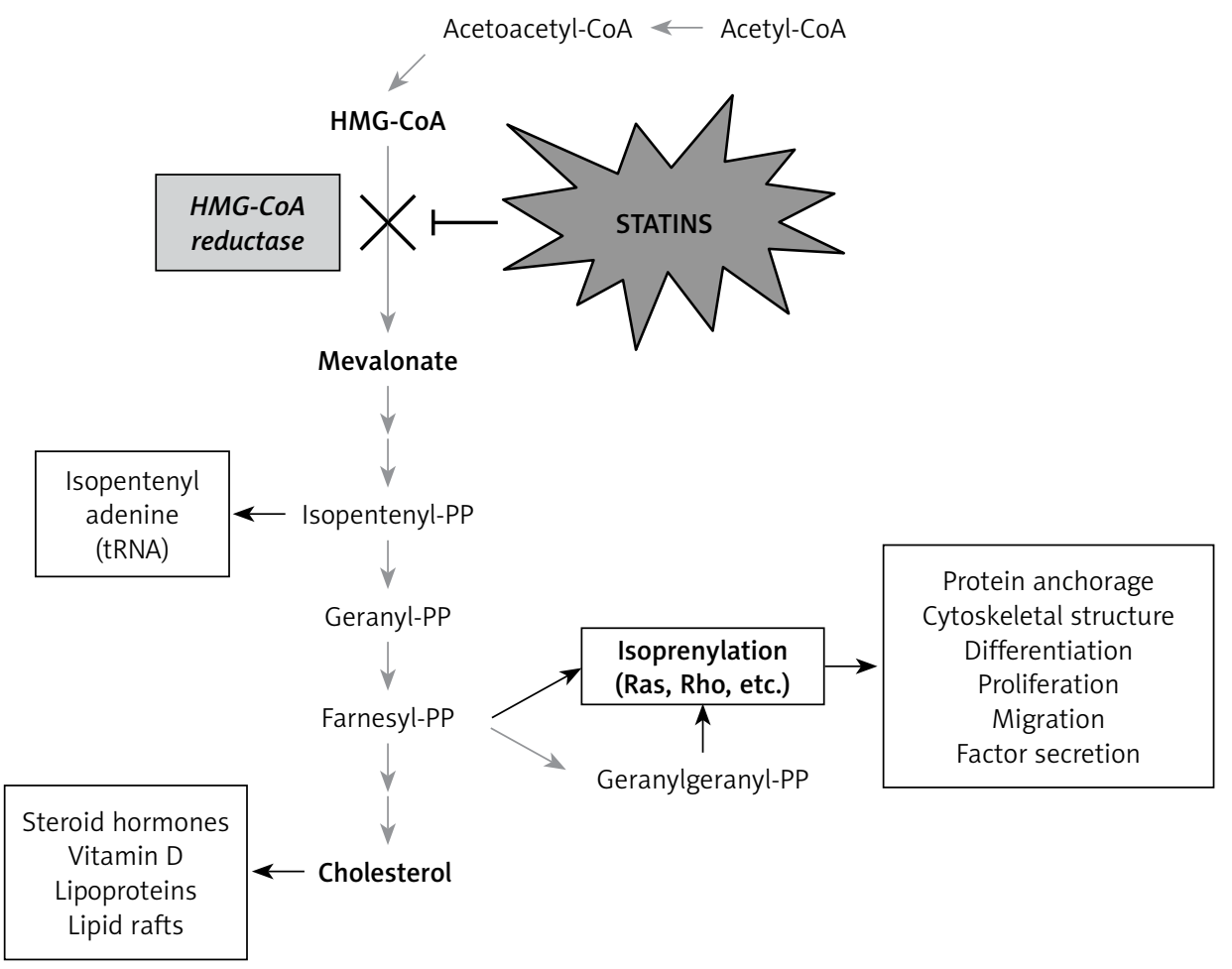

Figure 2. The most important effects of statins on lung cancer: inhibiting 3-hydroxy-3-methylglutaryl coenzyme A (HMG-CoA) reductase, stopping the mevalonate production from HMG-CoA and reducing mevalonate level, inhibiting myocardial Rac1-GTPase activity in order to suppress the NADPH oxidase activity and ROS generation. Also statins are inhibitors of farnesyltransferase (FT) proteins, RAF/ERK and AKT pathways, inhibitors of the EGFR and anti-apoptotic protein Mcl-1 in animals and humans. Additionally, they have effects on cellular energy homeostasis by inducing LKB1 and AMPK activation, and by inducing p53 pathway and G1 cell cycle arrest, which prevents DNA damage

tatin monotherapy overcoming erlotinib resistance in K-ras mutated NSCLC and relying only on apoptosis [101]. Hu et al. demonstrated that pitavastatin can inhibit LC cells and angiogenesis, which was achieved by the induction of apoptosis and inhibition of proliferation of LC cells and human lung tumor-associated endothelial cells. They also demonstrated that pitavastatin acted on LC cells and human lung tumor-associated endothelial cell by suppressing prenylation-dependent Ras/ Raf/MEK and PI3K/Akt/mTOR signaling [102].

In a meta-analysis on the antitumor effects of statins, it was found that patients who suffered from lung tumors and used statins had better overall survival than other patients who did not use statins. Subgroup analyses were performed as well, indicating that use of statins in stage IV LC was associated with a better survival rate when compared to other stages [103].

In a case-control study Khurana et al. evaluated the anti-tumor effects of statins in patients with LC. Based on the results of this study, the use of statins reduced the risk of $L C$ in the veteran population [104].

In a study by Omori et al. on patients with NSCLC, the results demonstrated that the use of statins with nivolumab improved the treatment of patients when compared to those who were not treated with statins [105].

\section{Conclusions}

This review presents the possible mechanisms of statins including lovastatin, atorvastatin, simvastatin, fluvastatin, rosuvastatin, pitavastatin and pravastatin for the prevention and treatment of $L C$ (Figure 2). Pre-clinical studies and animal models of cancer therapy indicate the antitumor effects of statins on various types of cancer, especially LC. On the basis of these studies, some potential antitumor properties of statins have been identified and reported. However, the molecular pathways and intracellular signaling cascades involved in the inhibition of cancer are very broad and complex, and there is a clear need for further studies.

Epidemiological studies have also illustrated that there might be a correlation between the use of statins and the reduction of LC risk. However, because clinical studies are very limited, the usefulness of statins to help treating LC cannot be definitively assessed. Phase II and III clinical studies on a large number of patients are needed to demonstrate the possible antitumor 
Table I. Statins for treatment of lung cancer

\begin{tabular}{|c|c|c|c|c|}
\hline $\begin{array}{l}\text { Type of statin/ } \\
\text { doses of agent }\end{array}$ & Mechanism & Investigated cell type & Result & $\begin{array}{l}\text { Ref. } \\
\text { no. }\end{array}$ \\
\hline \multicolumn{5}{|l|}{ Lovastatin: } \\
\hline $50 \mu \mathrm{M}$ & $\begin{array}{l}\text { COX- } 2 \text { activation } \\
\text { of PPAR } \gamma\end{array}$ & $\begin{array}{l}\text { A549 and H358 lung } \\
\text { carcinoma cells }\end{array}$ & $\begin{array}{l}\text { Human lung cancer cell } \\
\text { death }\end{array}$ & {$[53]$} \\
\hline 0,160 , or 400 ppm & $\begin{array}{l}\text { Inhibited ras } \\
\text { farnesylation }\end{array}$ & $\begin{array}{c}\mathrm{NCl}-\mathrm{H} 125, \mathrm{H} 292, \mathrm{H} 441, \\
\mathrm{H} 460, \text { and } \mathrm{H} 661\end{array}$ & $\begin{array}{l}\text { Lovastatin inhibited } \\
\text { the growth in vitro } \\
\text { of mouse }\end{array}$ & {$[58]$} \\
\hline $\begin{array}{l}5 \mu \mathrm{M} \text { in } \mathrm{A} 549 \\
1 \mu \mathrm{M} \text { in } \mathrm{H} 460\end{array}$ & $\begin{array}{l}\text { Inhibition of both RAF/ } \\
\text { ERK and AKT pathways }\end{array}$ & Human NSCLC lines & $\begin{array}{l}\text { Overcame gefitinib } \\
\text { resistance }\end{array}$ & {$[56]$} \\
\hline $5 \mu \mathrm{M}$ & $\begin{array}{l}\text { Induction of the ISR } \\
\text { and inhibition } \\
\text { of the EGFR }\end{array}$ & SCC & Apoptosis in SCC cells & {$[54]$} \\
\hline $1-25 \mu M$ & $\begin{array}{l}\text { Induced LKB1 and } \\
\text { AMPK activation }\end{array}$ & $\begin{array}{l}\text { A549, HeLa, SCC9, SCC25 } \\
\text { cell lines }\end{array}$ & $\begin{array}{l}\text { Regulating lovastatin- } \\
\text { induced cytotoxicity }\end{array}$ & {$[57]$} \\
\hline $2.5-20 \mu \mathrm{M}$ & $\begin{array}{c}\text { Anti-proliferation } \\
\text { mechanism of MCM2 }\end{array}$ & Human NSCLC & Activation of apoptosis & {$[61]$} \\
\hline $20 \mu \mathrm{M}$ & $\begin{array}{l}\text { A p53-independent } \\
\text { mitochondrial- } \\
\text { mediated apoptotic } \\
\text { mechanism }\end{array}$ & $\begin{array}{l}\text { BJMC3879 mammary } \\
\text { adenocarcinoma cell line }\end{array}$ & $\begin{array}{l}\text { Tumor volumes were } \\
\text { significantly reduced }\end{array}$ & {$[65]$} \\
\hline $2 \mu \mathrm{M}$ & $\begin{array}{l}\text { Inhibition of DNA } \\
\text { damage-dependent } \\
\text { G0/G1 }\end{array}$ & MCF-7 and A549 & $\begin{array}{c}\text { Improvement } \\
\text { of the therapeutic } \\
\text { index of cisplatin-based } \\
\text { chemotherapy }\end{array}$ & {$[60]$} \\
\hline \multicolumn{5}{|l|}{ Atorvastatin: } \\
\hline $1-10 \mu \mathrm{M}$ in vitro & $\begin{array}{c}\text { Reduced the growth } \\
\text { of xenograft and } \\
\text { inhibition of AKT } \\
\text { activity }\end{array}$ & A549 and $\mathrm{H} 1299$ & $\begin{array}{c}\text { Atorvastatin overcame } \\
\text { carboplatin resistance in } \\
\text { lung cancer }\end{array}$ & [69] \\
\hline $\begin{array}{l}5 \mu \mathrm{M} \text { in vitro } \\
10 \mathrm{mg} / \mathrm{kg} \text { in vivo }\end{array}$ & $\begin{array}{l}\text { Suppression of Rac1/ } \\
\text { NADPH oxidase activity }\end{array}$ & $\begin{array}{l}\text { Non-small cell lung } \\
\text { cancers (NSCLCs) } \\
\text { A549 cells }\end{array}$ & $\begin{array}{c}\text { Inhibit VEGF expression } \\
\text { via inhibition of ROS } \\
\text { production }\end{array}$ & [106] \\
\hline $\begin{array}{l}1 \text { or } 5 \mu \mathrm{M} \text { in vitro } \\
1 \text { or } 10 \mathrm{mg} / \mathrm{kg} \text { in vivo }\end{array}$ & $\begin{array}{l}\text { Suppression of AKT } \\
\text { and ERK activity }\end{array}$ & A549 and Calu1 cells & $\begin{array}{l}\text { Atorvastatin + gefitinib } \\
\text { inhibited proliferation and } \\
\text { promoted cell apoptosis }\end{array}$ & {$[107]$} \\
\hline $\begin{array}{l}1-8 \mu \mathrm{M} \text { in vitro } \\
200 \text { or } 400 \mathrm{ppm} \\
\text { in vivo }\end{array}$ & $\begin{array}{c}\text { Reducing the anti- } \\
\text { apoptotic protein } \mathrm{Mcl}-1 \\
\text { and increasing cleaved } \\
\text { caspase-3 }\end{array}$ & $\begin{array}{l}\text { Human lung cancer } \\
\text { H1299 and H460 cell } \\
\text { lines }\end{array}$ & $\begin{array}{l}\text { PPE plus atorvastatin } \\
\text { synergistically inhibited } \\
\text { lung tumorigenesis }\end{array}$ & {$[70]$} \\
\hline \multicolumn{5}{|l|}{ Simvastatin: } \\
\hline $50 \mu \mathrm{M}$ in vitro & Akt signaling & $\begin{array}{c}\text { A549 lung carcinoma } \\
\text { cells }\end{array}$ & $\begin{array}{l}\text { Inhibited the proliferation } \\
\text { of A549 lung cancer cells }\end{array}$ & {$[53]$} \\
\hline $2.5-30 \mu M$ & $\begin{array}{c}\text { Protein RAS, matrix } \\
\text { metalloproteinases and } \\
\text { NFא-B }\end{array}$ & Lung neoplastic cells & $\begin{array}{c}\text { Inhibition of cancer } \\
\text { growth in vitro }\end{array}$ & {$[58]$} \\
\hline $20 \mu \mathrm{M}$ & $\begin{array}{l}\text { Activation of Bax } \\
\text { and down-regulation } \\
\text { of BCL-2 gene } \\
\text { expression }\end{array}$ & $\begin{array}{l}\text { MCF7 human breast } \\
\text { cancer cells }\end{array}$ & $\begin{array}{l}\text { Inhibits cancer cell growth } \\
\text { by inducing apoptosis }\end{array}$ & {$[108]$} \\
\hline $1,10,20,100 \mu \mathrm{M}$ & $\begin{array}{c}\text { Induced G1 cell cycle } \\
\text { arrest }\end{array}$ & $\mathrm{NCl}-\mathrm{H} 460$ cells & Anti-cancer properties & {$[57]$} \\
\hline $2 \mu \mathrm{M}$ & $\begin{array}{l}\text { Expression of BIM and } \\
\text { inhibition of ERK }\end{array}$ & H1975 cells & Activation of apoptosis & {$[76]$} \\
\hline
\end{tabular}


Table I. Cont.

\begin{tabular}{|c|c|c|c|c|}
\hline $\begin{array}{l}\text { Type of statin/ } \\
\text { doses of agent }\end{array}$ & Mechanism & Investigated cell type & Result & $\begin{array}{l}\text { Ref. } \\
\text { no. }\end{array}$ \\
\hline \multicolumn{5}{|l|}{ Fluvastatin: } \\
\hline $0,5,10,20,40 \mu \mathrm{M}$ & $\begin{array}{l}\text { Down-regulating } \\
\text { of STAB1 expression } \\
\text { level via the Wnt/ } \\
\beta \text {-catenin pathway }\end{array}$ & $\begin{array}{l}\text { Human NSCLC cell line } \\
\text { H292 }\end{array}$ & $\begin{array}{c}\text { Reduced cell proliferation } \\
\text { and invasion }\end{array}$ & [80] \\
\hline $10 \mu \mathrm{M}$ & $\begin{array}{c}\text { Inhibited bone } \\
\text { metastasis through } \\
\text { induction of p53- } \\
\text { dependent autophagy } \\
\text { process }\end{array}$ & $\begin{array}{l}\text { A549 and SPC-A-1, } \\
\text { and animal model }\end{array}$ & Reduced bone metastasis & [81] \\
\hline $1-3 \mu \mathrm{M}$ & $\begin{array}{c}\text { In combination with } \\
\text { trametinib, blocked } \\
\text { Ras and PI3K signaling } \\
\text { pathways }\end{array}$ & $\begin{array}{l}\text { Drosophila models } \\
\text { and A549 cell line }\end{array}$ & $\begin{array}{l}\text { Showed synergistic } \\
\text { suppression of tumor } \\
\text { progression and viability }\end{array}$ & [82] \\
\hline \multicolumn{5}{|l|}{ Pravastatin: } \\
\hline NA & $\begin{array}{l}\text { Chemopreventive effect } \\
\text { against lung cancer }\end{array}$ & $\begin{array}{c}\text { Lung cancer in COPD } \\
\text { patients }\end{array}$ & $\begin{array}{l}\text { Decreased lung cancer } \\
\text { risk remarkably }\end{array}$ & [89] \\
\hline $40 \mathrm{mg}$ & NA & $\begin{array}{l}\text { Multicenter, phase III, } \\
\text { randomized, double- } \\
\text { blind, clinical trial }\end{array}$ & $\begin{array}{l}\text { Did not present any } \\
\text { benefit in the patients }\end{array}$ & [97] \\
\hline \multicolumn{5}{|l|}{ Rosuvastatin: } \\
\hline NA & $\begin{array}{l}\text { Chemopreventive effect } \\
\text { against lung cancer }\end{array}$ & $\begin{array}{l}\text { Lung cancer in COPD } \\
\text { patients }\end{array}$ & $\begin{array}{l}\text { Decreased lung cancer } \\
\text { risk remarkably }\end{array}$ & [89] \\
\hline $\begin{array}{l}1.25,2.5,5,10 \\
30 \mu \mathrm{M}\end{array}$ & $\begin{array}{l}\text { Inhibited cell } \\
\text { proliferation }\end{array}$ & Lung cancer tissues & $\begin{array}{c}\text { Suppression of RAS } \\
\text { protein, matrix } \\
\text { metalloproteinases } \\
\text { (MMP-2/9) and NF-kB-p65 } \\
\text { expression }\end{array}$ & {$[90]$} \\
\hline \multicolumn{5}{|l|}{ Pitavastatin: } \\
\hline $10 \mu M$ & $\begin{array}{l}\text { Induced cell death in } \\
\text { EGFR TKI resistant cells }\end{array}$ & $\begin{array}{l}\text { A549, Calu6 and } \mathrm{H} 1993 \\
\text { in vitro }\end{array}$ & $\begin{array}{l}\text { Induced cell death in EGFR } \\
\text { TKI resistant NSCLC cells } \\
\text { lines }\end{array}$ & [109] \\
\hline $1-5 \mu \mathrm{M}$ & $\begin{array}{c}\text { By suppressing } \\
\text { prenylation-dependent } \\
\text { Ras/Raf/MEK and PI3K/ } \\
\text { Akt/mTOR signaling }\end{array}$ & $\begin{array}{l}\text { Human lung tumor- } \\
\text { associated endothelial } \\
\text { cell }\end{array}$ & $\begin{array}{l}\text { Induction of apoptosis and } \\
\text { inhibition of proliferation }\end{array}$ & [110] \\
\hline
\end{tabular}

COX - cyclooxygenase, NSCLC - non-small cell lung cancer, SCC - squamous cell carcinomas, COPD - chronic obstructive pulmonary disease, PPAR - peroxisome proliferator activated receptor $\gamma$, EGFR - epidermal growth factor receptor, ISR - integrated stress response, $P P E$ - green tea polyphenol, NM - not mentioned.

effects of statins in different types of lung tumors. It is quite obvious that statins will never be drugs for LC treatment. Nevertheless, if proven so, they might be a useful supplemental tool and an additional treatment to all the other well-established therapies for LC management (Table I) [106-113].

\section{Conflict of interest}

The authors declare no conflict of interest.

\section{References}

1. Wen J, Fu J, Zhang W, Guo M. Genetic and epigenetic changes in lung carcinoma and their clinical implications. Mod Pathol 2011; 24: 932-43.
2. Xu R, Han Y. Long non-coding RNA FOXF1 adjacent noncoding developmental regulatory RNA inhibits growth and chemotherapy resistance in non-small cell lung cancer. Arch Med Sci 2019; 15: 1539-46.

3. Liu X, Wang M, Cui Y. LncRNA TP73-AS1 interacted with miR-141-3p to promote the proliferation of non-small cell lung cancer. Arch Med Sci 2019; 15: 1547-54.

4. Xu R, Han Y. Long non-coding RNA FOXF1 adjacent noncoding developmental regulatory RNA inhibits growth and chemotherapy resistance in non-small cell lung cancer. Arch Med Sci 2019; 15: 1539-46.

5. Shepherd FA, Rodrigues Pereira J, Ciuleanu T, et al. Erlotinib in previously treated non-small-cell lung cancer. N Engl J Med Overseas Ed 2005; 353: 123-32.

6. Torre LA, Siegel RL, Jemal A. Lung cancer statistics. In: Lung Cancer and Personalized Medicine. Ahmad A, Gadgeel S (eds). Springer 2016; 1-19. 
7. Barrera G. Oxidative stress and lipid peroxidation products in cancer progression and therapy. ISRN Oncol 2012; 2012: 137289.

8. Mazidi M, Katsiki N, Mikhailidis DP, Radenkovic D, Pella D, Banach M. Apolipoprotein B/apolipoprotein A-I ratio is a better predictor of cancer mortality compared with C-reactive protein: results from two multi-ethnic US populations. J Clin Med 2020; 9: 170.

9. Siegel RL, Miller KD, Jemal A. Cancer statistics, 2016. CA Cancer J Clin 2016; 66: 7-30.

10. Ma X, Liang AL, Liu YJ. Research progress on the relationship between lung cancer drug-resistance and microRNAs. J Cancer 2019; 10: 6865-75.

11. Kuczynski EA, Reynolds AR. Vessel co-option and resistance to anti-angiogenic therapy. Angiogenesis 2020; 23: 55-74.

12. Momtazi-Borojeni AA, Nik ME, Jaafari MR, Banach $M$, Sahebkar A. Potential anti-tumor effect of a nanoliposomal antiPCSK9 vaccine in mice bearing colorectal cancer. Arch Med Sci 2019; 15: 559-69.

13. Momtazi-Borojeni AA, Nik ME, Jaafari MR, Banach $M$, Sahebkar A. Effects of immunization against PCSK9 in an experimental model of breast cancer. Arch Med Sci 2019; 15: 570-9.

14. Sahebkar A, Watts GF. New therapies targeting apoB metabolism for high-risk patients with inherited dyslipidaemias: what can the clinician expect? Cardiovasc Drugs Ther 2013; 27: 559-67.

15. Banach M, Aronow WS, Serban C, et al. Lipids, blood pressure and kidney update 2014. Pharmacol Res 2015; 95-96: 111-25.

16. Soran H, Adam S, Mohammad JB, et al. Hypercholesterolaemia - practical information for non-specialists. Arch Med Sci 2018; 14: 1-21.

17. Reiner Ž. Statins in the primary prevention of cardiovascular disease. Nat Rev Cardiol 2013; 10: 453-64.

18. Kwon YJ, You NY, Lee JW, Kim J, Kang HT. High receipt of statins reduces the risk of lung cancer in current smokers with hypercholesterolemia: the national health insurance service-health screening cohort. Clin Lung Cancer 2019; 20: e177-85.

19. Reiner Ž, Hatamipour M, Banach M, et al. Statins and the COVID-19 main protease: in silico evidence on direct interaction. Arch Med Sci 2020; 16: 490-6.

20. Chruściel P, Sahebkar A, Rembek-Wieliczko M, et al. Impact of statin therapy on plasma adiponectin concentrations: a systematic review and meta-analysis of 43 randomized controlled trial arms. Atherosclerosis 2016; 253: 194-208.

21. Parizadeh SMR, Azarpazhooh MR, Moohebati M, et al. Simvastatin therapy reduces prooxidant-antioxidant balance: results of a placebo-controlled cross-over trial. Lipids 2011; 46: 333-40.

22. Sahebkar A, Serban C, Ursoniu S, et al. The impact of statin therapy on plasma levels of von Willebrand factor antigen: systematic review and meta-analysis of Randomised placebo-controlled trials. Thromb Haemost 2016; 115: 520-32.

23. Sahebkar A, Serban C, Mikhailidis DP, et al.; Lipid and Blood Pressure Meta-analysis Collaboration (LBPMC) Group Association between statin use and plasma D-dimer levels. A systematic review and meta-analysis of randomised controlled trials. Thromb Haemost 2015; 114: 546-57.

24. Serban C, Sahebkar A, Ursoniu S, et al. A systematic review and meta-analysis of the effect of statins on plasma asymmetric dimethylarginine concentrations. Sci Rep 2015; 5: 9902.
25. Jafari M, Rezaei M, Kalantari H, Hashemitabar M. Determination of cell death induced by lovastatin on human colon cell line HT29 using the comet assay. Jundishapur J Nat Pharm Prod 2013; 8: 187-91.

26. Hassan M, Watari H, AbuAlmaaty A, Ohba Y, Sakuragi N. Apoptosis and molecular targeting therapy in cancer. Biomed Res Int 2014; 2014: 150845.

27. Endo A. A historical perspective on the discovery of statins. Proc Jpn Acad Ser B Phys Biol Sci 2010; 86: 484-93.

28. DeBose-Boyd RA. Feedback regulation of cholesterol synthesis: sterol-accelerated ubiquitination and degradation of HMG CoA reductase. Cell Res 2008; 18: 609-21.

29. Kim SW, Kang HJ, Jhon M, et al. Statins and inflammation: new therapeutic opportunities in psychiatry. Front Psychiatry 2019; 10: 103.

30. Alberts AW. Lovastatin and simvastatin - inhibitors of HMG CoA reductase and cholesterol biosynthesis. Cardiology 1990; 77 (Suppl 4): 14-21.

31. Horiguchi A, Sumitomo M, Asakuma J, Asano T, Asano T, Hayakawa M. 3-hydroxy-3-methylglutaryl-coenzyme a reductase inhibitor, fluvastatin, as a novel agent for prophylaxis of renal cancer metastasis. Clin Cancer Res 2004; 10 : 8648-55.

32. Staffa JA, Chang J, Green L. Cerivastatin and reports of fatal rhabdomyolysis. N Engl J Med 2002; 346: 539-40.

33. Scripture CD, Pieper JA. Clinical pharmacokinetics of fluvastatin. Clin Pharmacokinet 2001; 40: 263-81.

34. Haak E, Abletshauser C, Weber S, et al. Fluvastatin therapy improves microcirculation in patients with hyperlipidaemia. Atherosclerosis 2001; 155: 395-401.

35. Luvai A, Mbagaya W, Hall AS, Barth JH. Rosuvastatin: a review of the pharmacology and clinical effectiveness in cardiovascular disease. Clin Med Insights Cardiol 2012; 6: 54324.

36. Martin PD, Mitchell PD, Schneck DW. Pharmacodynamic effects and pharmacokinetics of a new HMG-CoA reductase inhibitor, rosuvastatin, after morning or evening administration in healthy volunteers. Br J Clin Pharmacol 2002; 54: 472-7.

37. McTaggart F. Comparative pharmacology of rosuvastatin. Atheroscler Suppl 2003; 4: 9-14.

38. Hatanaka T. Clinical pharmacokinetics of pravastatin. Clin Pharmacokinet 2000; 39: 397-412.

39. McTavish D, Sorkin EM. Pravastatin. Drugs 1991; 42: 65-89.

40. Singhvi S, Pan H, Morrison R, Willard D. Disposition of pravastatin sodium, a tissue-selective HMG-CoA reductase inhibitor, in healthy subjects. Br J Clin Pharmacol 1990; 29: 239-43.

41. Menter DG, Ramsauer VP, Harirforoosh S, et al. Differential effects of pravastatin and simvastatin on the growth of tumor cells from different organ sites. PLoS One 2011; 6: e28813.

42. Saito Y. Pitavastatin: an overview. Atheroscler Suppl 2011; 12: 271-6.

43. Hooff GP, Wood WG, Müller WE, Eckert GP. Isoprenoids, small GTPases and Alzheimer's disease. Biochim Biophys Acta 2010; 1801: 896-905.

44. Kuipers HF. CCR5 in multiple sclerosis: expression, regulation, and modulation by statins. Thesis; 2007.

45. Mignard V, Lalier L, Paris F, Vallette FM. Bioactive lipids and the control of Bax pro-apoptotic activity. Cell Death Dis 2014; 5: e1266.

46. Giam M, Huang DC, Bouillet P. BH3-only proteins and their roles inprogrammed cell death. Oncogene 2008; 27: $128-36$.

47. Dulak J, Józkowicz A. Anti-angiogenic and anti-inflammatory effects of statins: relevance to anti-cancer therapy. Curr Cancer Drug Targets 2005; 5: 579-94. 
48. Chen J, Liu B, Yuan J, et al. Atorvastatin reduces vascular endothelial growth factor (VEGF) expression in human non-small cell lung carcinomas (NSCLCS) via inhibition of reactive oxygen species (ROS) production. Mol Oncol 2012; 6: 62-72.

49. Pirro M, Ricciuti B, Rader DJ, Catapano AL, Sahebkar A, Banach M. High density lipoprotein cholesterol and cancer: marker or causative? Prog Lipid Res 2018; 71: 54-69.

50. Ganjali S, Ricciuti B, Pirro M, et al. High-density lipoprotein components and functionality in cancer: state-ofthe-art. Trends Endocrinol Metab 2019; 30: 12-24.

51. Penson P, Long DL, Howard G, et al. Associations between cardiovascular disease, cancer, and very low highdensity lipoprotein cholesterol in the REasons for Geo graphical and Racial Differences in Stroke (REGARDS) study. Cardiovasc Res 2019; 115: 204-12.

52. Mazidi M, Mikhailidis DP, Banach M. Associations between risk of overall mortality, cause-specific mortality and level of inflammatory factors with extremely low and high high-density lipoprotein cholesterol levels among American adults. Int J Cardiol 2019; 276: 242-7.

53. Walther U, Emmrich K, Ramer R, Mittag N, Hinz B. Lovastatin lactone elicits human lung cancer cell apoptosis via a COX-2/PPAR $\gamma$-dependent pathway. Oncotarget 2016; 7: 10345.

54. Niknejad N, Morley M, Dimitroulakos J. Activation of the integrated stress response regulates lovastatin-induced apoptosis. J Biol Chem 2007; 282: 29748-56.

55. Knox JJ, Siu LL, Chen E, et al. A phase I trial of prolonged administration of lovastatin in patients with recurrent or metastatic squamous cell carcinoma of the head and neck or of the cervix. Eur J Cancer 2005; 41: 523-30.

56. Park IH, Kim JY, Jung J, Han JY. Lovastatin overcomes gefitinib resistance in human non-small cell lung cancer cells with K-Ras mutations. Invest New Drugs 2010; 28: 791-9.

57. Ma L, Niknejad N, Gorn-Hondermann I, Dayekh K, Dimitroulakos J. Lovastatin induces multiple stress pathways including LKB1/AMPK activation that regulate its cytotoxic effects in squamous cell carcinoma cells. PLoS One 2012; 7: e46055.

58. Hawk MA, Cesen KT, Siglin JC, Stoner GD, Ruch RJ. In hibition of lung tumor cell growth in vitro and mouse lung tumor formation by lovastatin. Cancer Lett 1996; 109: 217-22.

59. Gibbs JB, Oliff A, Kohl NE. Farnesyltransferase inhibitors: Ras research yields a potential cancer therapeutic. Cell 1994; 77: 175-8.

60. Shi Y, Felley-Bosco E, Marti TM, Stahel RA. Differential effects of lovastatin on cisplatin responses in normal human mesothelial cells versus cancer cells: implication for therapy. PLoS One 2012; 7: e45354.

61. Zhang X, Teng Y, Yang F, et al. MCM2 is a therapeutic target of lovastatin in human non-small cell lung carcinomas. Oncol Rep 2015; 33: 2599-605.

62. Broitman SA, Wilkinson J, Cerda S, Branch SK. Effects of monoterpenes and mevinolin on murine colon tumor CT-26 in vitro and its hepatic "Metastases" in vitro. In: Dietary Phytochemicals in Cancer Prevention and Treatment. American Institute for Cancer Research (ed.). Springer 1996; 111-30.

63. Jani J, Specht S, Stemmler N, et al. Metastasis of B16F10 mouse melanoma inhibited by lovastatin, an inhibitor of cholesterol biosynthesis. Invasion Metastasis 1993; 13: 314-24.

64. Kusama T, Mukai M, Iwasaki T, et al. 3-hydroxy-3-methylglutaryl-coenzyme a reductase inhibitors reduce human pancreatic cancer cell invasion and metastasis. Gastroenterology 2002; 122: 308-17.
65. Shibata MA, Ito Y, Morimoto J, Otsuki Y. Lovastatin inhibits tumor growth and lung metastasis in mouse mammary carcinoma model: a p53-independent mitochondrial-mediated apoptotic mechanism. Carcinogenesis 2004; 25: 1887-98

66. Khurana V, Bejjanki HR, Caldito G, Owens MW. Statins reduce the risk of lung cancer in humans: a large casecontrol study of US veterans. Chest 2007; 131: 1282-8.

67. Cilla Jr DD, Whitfield LR, Gibson DM, Sedman AJ, Posvar EL. Multiple-dose pharmacokinetics, pharmacodynamics, and safety of atorvastatin, an inhibitor of HMGCoA reductase, in healthy subjects. Clin Pharmacol Ther 1996; 60: 687-95.

68. Brognard J, Clark AS, Ni Y, Dennis PA. Akt/protein kinase B is constitutively active in non-small cell lung cancer cells and promotes cellular survival and resistance to chemotherapy and radiation. Cancer Res 2001; 61: 3986-97.

69. Chen J, Lan T, Hou J, et al. Atorvastatin sensitizes human non-small cell lung carcinomas to carboplatin via suppression of AKT activation and upregulation of TIMP-1. Int J Biochem Cell Biol 2012; 44: 759-69.

70. Lu G, Xiao H, You H, et al. Synergistic inhibition of lung tumorigenesis by a combination of green tea polyphenols and atorvastatin. Clin Cancer Res 2008; 14: 4981-8.

71. Li Y, Fu J, Yuan X, Hu C. Simvastatin inhibits the proliferation of A549 lung cancer cells through oxidative stress and up-regulation of SOD2. Pharmazie 2014; 69: 610-4.

72. Han JY, Lim KY, Yu SY, Yun T, Kim HT, Lee JS. A phase 2 study of irinotecan, cisplatin, and simvastatin for untreated extensive-disease small cell lung cancer. Cancer 2011; 117: 2178-85.

73. Huang Q, Shen HM, Ong CN. Inhibitory effect of emodin on tumor invasion through suppression of activator protein-1 and nuclear factor-кB. Biochem Pharmacol 2004; 68: 361-71.

74. Liang YW, Chang CC, Hung CM, Chen TY, Huang TY, Hsu YC. Preclinical activity of simvastatin induces cell cycle arrest in $\mathrm{G} 1$ via blockade of cyclin D-Cdk4 expression in non-small cell lung cancer (NSCLC). Int J Mol Sci 2013; 14: 5806-16.

75. Nishikawa S, Menju T, Takahashi K, et al. Statins may have double-edged effects in patients with lung adenocarcinoma after lung resection. Cancer Manag Res 2019; 11: 3419-32.

76. Lee HY, Kim IK, Lee HI, et al. The apoptotic effect of simvastatin via the upregulation of BIM in nonsmall cell lung cancer cells. Exp Lung Res 2016; 42: 14-23.

77. Bocci G, Fioravanti A, Orlandi P, et al. Fluvastatin synergistically enhances the antiproliferative effect of gemcitabine in human pancreatic cancer MIAPaCa-2 cells. Br J Cancer 2005; 93: 319-30.

78. Taylor-Harding B, Orsulic S, Karlan BY, Li AJ. Fluvastatin and cisplatin demonstrate synergistic cytotoxicity in epithelial ovarian cancer cells. Gynecol Oncol 2010; 119: 549-56.

79. Zhang T, Bai R, Wang Q, et al. Fluvastatin inhibits HMGCoA reductase and prevents non-small cell lung carcinogenesis. Cancer Prev Res 2019; 12: 837-48.

80. Xu HY, Xue JX, Gao H, et al. Fluvastatin-mediated downregulation of SATB1 affects aggressive phenotypes of human non-small-cell lung cancer cell line H292. Life Sci 2019; 222: 212-20.

81. Yang Z, Su Z, DeWitt JP, et al. Fluvastatin prevents lung adenocarcinoma bone metastasis by triggering autophagy. EBioMedicine 2017; 19: 49-59.

82. Levine BD, Cagan RL. Drosophila lung cancer models identify trametinib plus statin as candidate therapeutic. Cell Rep 2016; 14: 1477-87. 
83. Nabati M, Janbabai G, Esmailian J, Yazdani J. Effect of rosuvastatin in preventing chemotherapy-induced cardiotoxicity in women with breast cancer: a randomized, single-blind, placebo-controlled trial. J Cardiovasc Pharmacol Ther 2019; 24: 233-41.

84. El Sayed I, Helmy MW, El-Abhar HS. Inhibition of SRC/ FAK cue: a novel pathway for the synergistic effect of rosuvastatin on the anti-cancer effect of dasatinib in hepatocellular carcinoma. Life Sci 2018; 213: 248-57.

85. Yokohama K, Fukunishi S, Li M, et al. Rosuvastatin as a potential preventive drug for the development of hepatocellular carcinoma associated with non-alcoholic fatty liver disease in mice. Int J Mol Med 2016; 38 : 1499-506.

86. Maj M, Czajkowski R, Zegarska B, Kowaliszyn B, Pokrywczynska M, Drewa T. Anti-proliferative and cytotoxic activity of rosuvastatin against melanoma cells. Adv Dermatol Allergol 2016; 33: 257-62.

87. Schupp N, Schmid U, Heidland A, Stopper H. Rosuvastatin protects against oxidative stress and DNA damage in vitro via upregulation of glutathione synthesis. Atherosclerosis 2008; 199: 278-87.

88. Janakiram NB, Mohammed A, Bryant T, et al. Potentiating NK cell activity by combination of rosuvastatin and difluoromethylornithine for effective chemopreventive efficacy against Colon Cancer. Sci Rep 2016; 14: 37046.

89. Liu JC, Yang TY, Hsu YP, et al. Statins dose-dependently exert a chemopreventive effect against lung cancer in COPD patients: a population-based cohort study. Oncotarget 2016; 7: 59618-29.

90. Falcone D, Gallelli L, Di Virgilio A, et al. Effects of simvastatin and rosuvastatin on RAS protein, matrix metalloproteinases and NF-KB in lung cancer and in normal pulmonary tissues. Cell Prolif 2013; 46: 172-82.

91. Lai SW, Liao KF, Lin CL, Sung FC, Cheng YH. Statins use and female lung cancer risk in Taiwan. Libyan J Med 2012; 7: 20123.

92. Coimbra M, Banciu M, Fens MH, et al. Liposomal pravastatin inhibits tumor growth by targeting cancer-related inflammation. J Control Release 2010; 148: 303-10.

93. Konings IR, van der Gaast A, van der Wijk LJ, de Jongh FE, Eskens FA, Sleijfer $S$. The addition of pravastatin to chemotherapy in advanced gastric carcinoma: a randomised phase II trial. Eur J Cancer 2010; 46: 3200-4.

94. Bujanda L, Rodríguez-González A, Sarasqueta C, et al. Effect of pravastatin on the survival of patients with advanced gastric cancer. Oncotarget 2016; 7: 4379-84.

95. Matsushita Y, Sugihara M, Kaburagi J, et al. Pravastatin use and cancer risk: a meta-analysis of individual patient data from long-term prospective controlled trials in Japan. Pharmacoepidemiol Drug Saf 2010; 19: 196-202.

96. Asakage M, Tsuno NH, Kitayama J, et al. 3-Hydroxy3-methylglutaryl-coenzyme A reductase inhibitor (pravastatin) inhibits endothelial cell proliferation dependent on G1 cell cycle arrest. Anticancer Drugs 2004; 15: 625-32.

97. Seckl MJ, Ottensmeier CH, Cullen M, et al. Multicenter phase III, randomized, double-blind, placebo-controlled trial of pravastatin added to first-line standard chemotherapy in small-cell lung cancer (LUNGSTAR). J Clin Oncol 2017; 35: 1506-14.

98. Brower V. Pravastatin has no advantage in small-cell lung cancer. Lancet Oncol 2017; 18: e204.

99. Taras D, Blanc J-F, Rullier A, et al. Pravastatin reduces lung metastasis of rat hepatocellular carcinoma via a coordinated decrease of MMP expression and activity. J Hepatol 2007; 46: 69-76.
100. Ferreira TS, Lanzetti M, Barroso MV, et al. Oxidative stress and inflammation are differentially affected by atorvastatin, pravastatin, rosuvastatin, and simvastatin on lungs from mice exposed to cigarette smoke. Inflammation 2014; 37: 1355-65.

101. Otahal A, Aydemir D, Tomasich E, Minichsdorfer C. Delineation of cell death mechanisms induced by synergistic effects of statins and erlotinib in non-small cell lung cancer cell (NSCLC) lines. Sci Rep 2020; 10: 959.

102. Hu T, Shen H, Huang H, Yang Z, Zhou Y, Zhao G. Cholesterol-lowering drug pitavastatin targets lung cancer and angiogenesis via suppressing prenylation-dependent Ras/Raf/MEK and PI3K/Akt/mTOR signaling. Anticancer Drugs 2020; 31: 377-84.

103. Chen Y, Li X, Zhang R, et al. Effects of statin exposure and lung cancer survival: a meta-analysis of observational studies. Pharmacol Res 2019; 141: 357-65.

104. Khurana V, Bejjanki HR, Caldito G, Owens MW. Statins reduce the risk of lung cancer in humans: a large casecontrol study of US veterans. Chest 2007; 131: 1282-8.

105. Omori M, Okuma Y, Hakozaki T, Hosomi Y. Statins improve survival in patients previously treated with nivolumab for advanced non-small cell lung cancer: an observational study. Mol Clin Oncol 2019; 10: 137-43.

106. Chen J, Liu B, Yuan J, et al. Atorvastatin reduces vascular endothelial growth factor (VEGF) expression in human non-small cell lung carcinomas (NSCLCS) via inhibition of reactive oxygen species (ROS) production. Mol Oncol 2012; 6: 62-72.

107. Chen J, Bi H, Hou J, et al. Atorvastatin overcomes gefitinib resistance in KRAS mutant human non-small cell lung carcinoma cells. Cell Death Dis 2013; 4: e814.

108. Spampanato C, De Maria S, Sarnataro M, et al. Simvastatin inhibits cancer cell growth by inducing apoptosis correlated to activation of Bax and down-regulation of BCL-2 gene expression. Int J Oncol 2012; 40: 935-41.

109. Otahal A, Aydemir D, Tomasich E, Minichsdorfer Ch. Delineation of cell death mechanisms induced by synergistic effects of statins and erlotinib in non-small cell lung cancer cell (NSCLC) lines. Sci Rep 2020; 10: 959.

110. Hu T, Shen H, Huang H, Yang Z, Zhou Y, Zhao G. Cholesterol-lowering drug pitavastatin targets lung cancer and angiogenesis via suppressing prenylation-dependent Ras/Raf/MEK and PI3K/Akt/mTOR signaling. Anticancer Drugs 2020; 31: 377-84.

111. Banach M, Burchardt P, Chlebus K, et al. PoLA/CFPiP/ $\mathrm{PCS} / \mathrm{PSLD} / \mathrm{PSD} / \mathrm{PSH}$ guidelines on diagnosis and therapy of lipid disorders in Poland 2021. Arch Med Sci 2021; 17: 1447-547.

112. Huang N, Dai W, Li Y, et al. LncRNA PCAT-1 upregulates RAP1A through modulating miR-324-5p and promotes survival in lung cancer. Arch Med Sci 2020; 16: 1196-206.

113. Pu R, Pu M, Huang H, Cui Y. MicroRNA 144 inhibits cell migration and invasion and regulates inflammatory cytokine secretion through targeting toll like receptor 2 in non-small cell lung cancer. Arch Med Sci 2021; 17: 1028-37. 